\title{
Engelske lån i dansk: \\ Nice to have eller need to have?
}

\author{
MARGRETHE HEIDEMANN ANDERSEN
}

\begin{abstract}
Den engelske påvirkning af dansk er et emne der ofte debatteres i Danmark, men holdningerne til om den er en trussel eller ej, er delte. Mens mange medier og sprogbrugere opfatter engelskpåvirkningen som kraftig og potentielt truende, betragter mange sprogfolk påvirkningen som mindre kraftig og ikketruende. Tidligere undersøgelser af almensproget, defineret som det sprog man finder i landsdækkende aviser, har tidligere vist at mængden af engelske lån i løbende tekst er relativt beskeden, men andre tekstarter (fx ugeblade) kan være mere påvirkede end avissproget, ligesom især unges uformelle talesprog ofte nævnes som et område hvor man finder relativt mange engelske lån. I artiklen her undersøges det derfor hvor mange engelske lån der findes i en række ugeblade og i det sprog som unge anvender i realityprogrammet Ex on the Beach. Resultatet af undersøgelsen er at mængden af engelske lån også her er meget begrænset, men at forskellige faktorer kan få engelskpåvirkningen til at virke større end den reelt er. Ikke mindst det at engelske lån som regel ikke tilpasses dansk ortografi og fonologi, og at der findes relativt mange engelske lån i nogle bestemte pågående genrer, fx reklamer og annoncer, har betydning for den almindelige sprogbrugers opfattelse af hvor kraftig engelskpåvirkningen er.
\end{abstract}

EMNEORD: engelskpåvirkning; importord; låneord; kontaktlingvistik

\section{INDLEDNING}

I Flensborg Avis kunne man d. 21. oktober 2019 læse at "Engelske ord og vendinger strømmer ind i det danske sprog. Ord som cougar, instagramme og mansplaine er for nylig blevet tilføjet som opslagsord i dansk. Men det kan være udtryk for en faretruende tendens, som i sidste ende kan slå det danske sprog ihjel” (Bager Gandrup 2019). I Berlingske Tidende kunne man d. 20. januar 2019 læse at ny forskning dokumenterer at $10 \%$ af vores ordforråd nu stammer fra engelsk (Sturlason 
2019), mens en pressemeddelelse fra Dansk Sprognævn d. 18. november 2019 meddelte at en forskningsrapport fra nævnet kunne dokumentere at engelsk ikke udgør en trussel mod dansk skriftsprog (Dansk Sprognævn 2019). Denne pressemeddelelse førte til at en journalist fra Bornholms Tidende d. 25. januar 2020 gjorde sig til talsmand for det synspunkt at forskellen mellem det skrevne (avis)sprog og det talte sprog bliver større og større fordi engelsk "i de sidste 20 år er kommet til at fylde mere og mere i det talte hverdagssprog" (Nørmark 2020). Meningerne om hvorvidt dansk er truet eller ej, er altså delte, og for den enkelte sprogbruger må det være vanskeligt at sondre mellem de forskellige udsagn og resultater: Er dansk egentlig truet af engelsk eller ej? Når det spørgsmål ikke kan besvares med et enkelt ja eller nej, skyldes det bl.a. de vanskeligheder der er forbundet med at måle engelskpåvirkningen:

Estimating the frequency of English elements is far from easy. Do we include all words regardless of their age and regardless whether they are completely established and do not differ from native words (e.g. Swedish jobb)? Do we include all types of borrowings/code-switches? Do we include words which have been borrowed from English, but derive originally from other languages (e.g. Swedish jungel through English jungle from Hindi jangal)? What do we do with international words like Swedish frustration and signifikant from English frustration and significant? And, not least, what types of texts are we talking about? We may get different results depending upon how we answer these questions. (Johansson 2002: 94)

At forskningsrapporten fra Dansk Sprognævn (Heidemann Andersen 2019a) fastslår at mængden af engelske lån er beskeden i avissprog, er således ikke automatisk det samme som at mængden af engelske lån dermed er tilsvarende beskeden $i$ andre tekstarter eller i talesproget. Forskningsrapporten kan kun sige noget om netop dén teksttype der undersøges, ikke noget om andre teksttyper eller om talesproget, hvilket ikke altid er lige klart for sprogbrugerne. Dertil kommer at de grundlæggende spørgsmål som Johansson opstiller, fx hvad der regnes 
for et engelsk lån, ofte bliver besvaret på forskellig vis af sprogforskerne (jf. Graedler 2007: 157 f.), og det gør det vanskeligt at sammenligne de enkelte undersøgelser. Det interessante er at uanset hvilke kriterier man har opstillet for hvad det er man vil undersøge, konkluderer undersøgelserne stort set alle at mængden af engelske lån, beregnet som frekvenser i løbende tekst, uanset hvilken teksttype der er tale om, er relativt beskeden. Det er et resultat der ikke umiddelbart harmonerer med den bekymring mange danske sprogbrugere og medier giver udtryk for, en bekymring som man også kan finde i de andre nordiske sprogsamfund. Dermed er der altså et modsætningsforhold mellem det resultat sprogforskernes frekvensbaserede undersøgelser giver, og den almindelige sprogbrugers opfattelse af nationalsprogenes tilstand. Dette modsætningsforhold forklarer den svenske sprogforsker Mall Stålhammar således:

English words account for only a small percentage in running text, generally between one half and two per cent (Ljung 1985:157-162), a natural consequence of the structure of the language, where functional words like pronouns, auxiliaries, etc. necessarily dominate. Still, many people complain that English dominates - which may be true on another level than that of mathematics: loanwords are often nouns that tend to be central to the understanding of a text. Thus they carry more weight than their statistical due.

English loanwords also tend to be used in contexts designed to attract attention, like advertising, or by language users who are associated with power and/or money, like economists, technical specialists, and scientists.

Complaints about the omnipresence of English may thus be the case of confusing the messenger and the message: dislike of a commercialised, globalised world dominated by English-speaking cultures is expressed as criticism of the language used in this world. (2004: 97)

Stålhammar peger altså på at selvom de engelske lån er i mindretal i forhold til det resterende ordforråd, repræsenterer de ofte en kommerciel, globaliseret kultur, og at det man reagerer på når man bekymres over 
de engelske lån, dermed måske ikke er ordene som sådan, men derimod den især amerikanske dominans som lånene repræsenterer. I Danmark har bl.a. professor Michael Herslund været fortaler for en lignende holdning, altså at det ikke er de enkelte låneord vi skal være bekymrede for, men derimod det de repræsenterer, det vil sige "det latterlige og hovedløse snobberi" over for amerikansk kultur (Herslund 1999: 19).

Det hidtil største forskningsprojekt der har undersøgt engelskpåvirkningen af de nordiske sprog, er projektet Moderne Importord $i$ Norden (herefter omtalt MiN-projektet), hvor forskere fra hele Norden målte tilvæksten af såkaldt moderne importord, dvs. alle indlånte ord der ifølge ordbøgerne er blevet registreret i de undersøgte sprog efter 1945, i avistekster ${ }^{1}$ fra hhv. 1975 og 2000. På baggrund af MiN-projektet undersøgte forskere fra Dansk Sprognævn efterfølgende den fremmedsproglige påvirkning af dansk skriftsprog i de samme avistyper fra 2016 i projektet Moderne Importord i Dansk (herefter kaldet MiD-projektet).

De to projekter har tilvejebragt ny viden om engelskpåvirkningen af såvel dansk som nordisk skriftsprog ud fra sammenlignelige metoder, men altså kun med udgangspunkt $\mathrm{i}$ avistekster. Formålet med artiklen her er at supplere MiN- og MiD-projektet med yderligere undersøgelser af engelskpåvirkningen af andre områder af dansk skriftsprog og $\mathrm{i}$ en del af talesproget for dermed at give et mere velfunderet udgangspunkt for en beskrivelse af engelskpåvirkningen end den der er baseret på avissprog alene. Disse supplerende undersøgelser er udført ud fra de samme kriterier som i MiN- og MiD-projektet hvorved resultaterne altså kan sammenlignes direkte.

\section{HVORDAN MÅLES ENGELSKPÅVIRKNINGEN?}

Engelskpåvirkningen af de nordiske sprog er som oftest blevet målt i form af frekvensoptællinger af forskellige typer engelske lån, først og fremmest i avistekster (Graedler 2007: 158 f.). Valget af avistekster begrundes med at man her finder den bedste repræsentant for "almensproget" (Chrystal 1988: 33 f.), ikke mindst i forhold til den redaktionelle tekst der repræsenterer "normalprosaen i skriftspråka" (Selback og Sandøy 2007: 11). Avissprog udgør dog kun en del af det

1 De undersøgte aviser var Politiken, Århus Stiftstidende og en tabloidavis (Ekstra Bladet i MiN-projektet, BT i MiD-projektet, jf. Heidemann Andersen 2019a: 33 f.). 
skriftsprog som møder os i dagligdagen, og da vi ved at det redaktionelle avissprog i nordiske aviser indeholder relativt få engelske lån i sammenligning med andre tekstarter og genrer (jf. Graedler 2007: 164 ff.), og at tekstarten $i$ øvrigt er den variabel der har størst betydning for antallet af engelske lån (jf. Johansson 2002: 95), kan man argumentere for at avisundersøgelserne ikke bør stå alene. Dette synspunkt underbygges af at man også kan diskutere om avistekster er den bedste repræsentant for det skriftlige almensprog (jf. Diderichsen 2019), og om man i stedet - eller som supplement - burde inddrage andre tekstarter, fx ugebladstekster, der af Hanne Ruus defineres som den tekstart der har det mindst påfaldende ordforråd (Ruus 1995: 39).

En anden måde at måle engelskpåvirkningen på er at finde antallet af engelske lån i det centrale skriftsproglige ordforråd. Det centrale ordforråd bestemmes vha. hyppighedsundersøgelser, der i nordisk sammenhæng som oftest enten er baseret på avistekster eller på de mest læste tekstarter (dvs. aviser, ugeblade, romaner, børnebøger og fagblade), i en afgrænset periode (Maegaard og Ruus 1978: 47 ff.). Den bagvedliggende teori er at disse tekstarter er de bedste repræsentanter for den del af vores ordforråd som vi er fælles om, dvs. ord som son, datter, ko, hest, arme, krop, ansigt og hals. Hyppighedsundersøgelserne siger dermed ikke noget om den del af ordforrådet som vi ikke er fælles om, fx ord der er relateret til vores fag, arbejde og færdigheder der hører fritiden til (Ruus 1991: 158). I betragtning af at undersøgelser har vist at relativt mange af de engelske lån man finder $i$ avistekster, er uetablerede lejlighedsdannelser eller lavfrekvente ord (jf. Chrystal 1988, Diderichsen 2019), kan man diskutere i hvilken udstrækning hyppighedsundersøgelser alene kan bruges som indikator for den generelle engelskpåvirkning af vores sprog. I forhold til engelskpåvirkningen er hyppighedsundersøgelser dog især interessante fordi man på baggrund af dem kan afgøre hvor mange af de såkaldte kerneord der er af engelsk oprindelse. Et kerneord er af Hanne Ruus blevet defineret som et ord der forekommer meget hyppigt (dvs. mindst 20 gange) $\mathrm{i}$ et korpus baseret på ugebladstekster, der som nævnt er bestemt som den af de mest læste tekstarter der har det mindst påfaldende ordforråd (Ruus 1995). Et kerneord tilhører med andre ord det helt centrale ordforråd. Ét af de ofte fremførte argumenter for at 
engelskpåvirkningen af dansk er relativt beskeden, er at de engelske lån ikke befinder sig i ordforrådets centrale del, altså blandt kerneordene, men derimod i yderkanten af ordforrådet (jf. Jarvad 2018: 439). Tidligere undersøgelser har fx peget på at der ikke findes engelske lån blandt de hyppigste ord i svensk, men derimod en del lån fra tysk (Gellerstam 1973), og lignende tal gør sig gældende for dansk (Jarvad 1995: 105). Nye undersøgelser viser dog at andelen af kerneord med engelsk oprindelse i dansk i dag er højere end tidligere (Schack 2019: 246), hvilket kan betragtes som et tegn på en stigende engelsk indflydelse på dansk skriftsprog.

Blandt de kerneord som Hanne Ruus har oplistet i sin undersøgelse, er der en stor del der kommer fra tysk, fx monster og stilling (Skovgaard Boeck 2018: 315 ff.), mens en mindre del, fx danse og dame, er fra de romanske sprog (Lorentzen 2018: 426 f.). Fælles for dem er at langt størstedelen ikke virker fremmede: De er blevet tilpasset dansk ortografi og morfologi og er altså fra en synkron synsvinkel hjemlige. Lidt anderledes forholder det sig med de kerneord der er af engelsk oprindelse idet de stort set alle afviger fra dansk ortografi og (i mindre grad) morfologi (jf. kerneord som baby, cool, design, interview og jeans, se Schack 2019: 246) og dermed føles mere fremmede end de kerneord der er af tysk eller romansk oprindelse. Med andre ord kan mængden af lån godt være relativt kraftig, men føles beskeden fordi ordene er tilpasset dansk (som med de tyske låneord), ligesom den kan være relativt beskeden, men føles kraftig (som med de engelske låneord). Dermed kan man argumentere for at frekvens ikke alene skal bruges som målestok for graden af engelskpåvirkning, men at man også bør tage højde for i hvor høj grad låneordene tilpasses modtagersprogets ortografi, morfologi og - hvis det drejer sig om talesprog - fonologi. I en svensk undersøgelse af mængden af engelske lån $i$ avistekster viser Chrystal således at den samlede mængde af engelske lån i avistekster er beskeden (1988: 190), men at $41 \%$ af de forskellige lån som anvendes $\mathrm{i}$ aviserne, ikke viser nogen som helst form for tilpasning til svensk ortografi og morfologi (1988: 192). Derved kommer de altså til at virke afstikkende i forhold til den omgivende tekst, og da mange af lånene desuden tiltrækker sig opmærksomhed på andre måder, fx ved at have en fremtrædende eller informationsbærende placering $i$ 
teksten eller ved at være markeret grafisk med kursiv, citationstegn og lignende, er det ifølge Chrystal "tänkbart att de engelska lånen i en text väger mycket tyngre än andra ord. Om så är fallet kan man inte grunda slutsatser om inflytandets storlek enbart på uppgifter om den faktiska frekvensen utan hänsyn måste även tas till språkpsykologiska aspekter på inflytandet” (1988: 192 f.).

Derudover findes der også relativt mange engelske lån i nogle bestemte særligt pågående genrer, fx reklamer, produktnavne, butiksskilte og lignende (Heidemann Andersen 2019b), dvs. genrer der er udformet på en sådan måde at de skal fange læserens opmærksomhed. Det gør man bl.a. ved at bruge engelske ord der kræver mere opmærksomhed af læseren fordi de er skrevet på et andet sprog end det hjemlige, hvorved læseprocessen forlænges, og opmærksomheden mod produktet fanges (Gerritsen og van Meurs 2013: 90 f.). En tysk undersøgelse peger desuden på at det $\mathrm{i}$ reklametekster især er overskrifter og slogans der skrives på engelsk, mens selve brødteksten er skrevet på tysk. I og med at overskrifter indrammer reklamebudskabet, og derudover ofte fremhæves grafisk, og slogans har en identitetsbærende funktion for det brand som de skal markedsføre (Pillar 2001: 160 f.), får brugen af engelsk altså en relativt fremtrædende plads i reklameteksten og dermed i sprogbrugernes bevidsthed.

Mange af disse faktorer gør sig naturligvis først og fremmest gældende der hvor de engelske lån ikke tilpasses modtagersprogets ortografi, hvilket fx gælder dansk (Jarvad 2019). Den manglende tilpasning af de engelske lån til især dansk ortografi betyder at en dansk tekst nemt kommer til at se mere engelskpræget ud end fx en norsk tekst, hvor mange af de engelske lån vil være tilpasset norsk ortografi og morfologi. Når det $i$ Norden er en gængs opfattelse at vi danskere bruger langt flere engelske lån end fx nordmænd og svenskere (Sandøy 2019: 359), skyldes det måske i højere grad vores manglende ortografiske tilpasning af låneordene end låneordenes antal som sådan.

Alt $i$ alt kan man konkludere at på trods af at antallet af engelske lån i forskellige undersøgelser har vist sig at være relativt beskedent, er der andre faktorer, $\mathrm{fx}$ de engelske låneords manglende tilpasning til dansk ortografi, låneordens grafiske fremtoning $i$ tekster og det at de ofte har en informationsbærende funktion, der bevirker at de kan have en 
mere dominerende plads i mange sprogbrugeres bevidsthed end deres frekvens egentlig berettiger til.

\section{LÅNEORDSTYPER}

Kontaktlingvistiske undersøgelser viser at sprogkontakt som regel først ses i form af leksikalske påvirkninger, mens strukturelle ændringer følger efter (Thomason og Kaufman 1988: 74 ff.; Winford 2010: 179; Haspelmath 2008: 48). I dansk (såvel som i de andre nordiske sprog, se Selback og Sandøy 2007) kommer den sproglige påvirkning i dag først og fremmest fra engelsk, og det er især ordforrådet der påvirkes (Pedersen 2000; Jarvad 2018). I nyere tid har vi dog set eksempler på andre ændringer af ordforrådet end blot indlånet af ord, fx ved at suffikset -ish vinder indpas i dansk ved siden af det oprindeligt tyske -agtig (Heidemann Andersen 2018), en påvirkning der også er dokumenteret i norsk (Nilssen 2015), og ved at den engelske bøjningsendelse $-s$ føres på såvel hjemlige ord ( $\mathrm{fx}$ tilbuds og kliks) som lån fra andre sprog end engelsk ( $\mathrm{fx}$ fifs og polterabends) (Nørby Jensen 2019: 206). Også dette fænomen findes i norsk hvor man har observeret engelsk flertals-s på ord som nettbretts og forums (Meland 2019). Derudover kan danske verber ændre konstruktionsmønster under indflydelse fra engelsk (Kirchmeier-Andersen 2009), men de eksempler vi ser på syntaktisk påvirkning, er ofte "enkeltstående tilfælde, ikke generelle påvirkninger" (Jarvad 2018: 448). Ifølge Thomason og Kaufman er "isolated examples of structural borrowing [...] not diagnostic unless we know enough to gauge the overall systematic effects” (1988: 77), og artiklens fokus vil derfor være på indlånet af engelske ord i dansk.

I nordisk låneordsforskning opererer man typisk med fire hovedtyper af leksikalske lån (Edlund og Hene 1992; Jarvad 1995; Sørensen 1995; Jarvad 2018; Sunde 2019), nemlig direkte lån, hybrider, pseudolån og indirekte lån. Direkte lån består af ord eller udtryk som er importeret direkte fra et fremmedsprog (her engelsk), og som altså i større eller mindre grad har beholdt deres ortografiske, morfologiske og fonologiske særpræg, jf. eksempler som phishing (der er helt utilpasset), bingewatche (der er tilpasset dansk morfologi) og nord (der er helt tilpasset dansk). Hybriderne er ord der består af såvel et dansk led som 
et fremmed led, fx bagcover, der er dannet efter det engelske ord back cover, og mobelpolish, der er dannet af furniture polish. Pseudolån består af ord der er dannet af fremmede elementer, men på et dansk grundlag, fx bake-off, og indirekte lån er ord der er dannet af dansk materiale, men har deres baggrund i engelsk; de indirekte lån kan inddeles i oversattelseslån (også kaldet kalker) og betydningslån (også kaldet semantiske lån). Oversattelseslan er ord der er en mere eller mindre direkte oversættelse fra engelsk, fx vejurede for roadrage, mens betydningslån er "gamle" ord der får ny betydning under indflydelse af et tilsvarende engelsk ord. Det gælder fx verbet adressere, der under indflydelse fra engelsk address nu ikke blot betyder 'forsyne et brev med modtagerens navn og adresse', men også 'tage fat på, bringe på bane' (jf. Skafte Jensen 2009). Oversattelseslan fører til dannelsen af nye ord (Capuz 1997: 88), mens betydningslån fører til homonymi. Dertil kommer eventuelle paralleldannelser der kan defineres som "ord og udtryk der kan være dannet med udgangspunkt $i$ et ord eller udtryk på et andet sprog, men som lige så godt kan være dannet herhjemme" (Nørby Jensen 2019: 209), fx energikrise (jf. engelsk energy crisis).

En særlig type lån som kun nogle få nævner, er pragmatiske lån der fx dækker over det at man på tysk bruger udtryk som Ich liebe dich/ hab' dich lieb (fx som afsluttende replik ved telefonsamtaler) og Haben Sie noch einen schönen Tag (når man forlader en butik), der begge kan betragtes som et udtryk for amerikansk kulturpåvirkning (Fiedler 2012: 256). Et dansk eksempel kunne være Jeg elsker dig (under påvirkning af engelsk I love you) i stedet for standardformen Hav det godt (Gottlieb 2019: 253). Sådanne pragmatiske lån kan tages som udtryk for en generel amerikanisering af vores samfund hvor fx omgangsformer og udtryk som vi i Danmark traditionelt har anset for at tilhøre intimsfæren, får en mere bred anvendelse, og det er ikke utænkeligt at det som mange sprogbrugere reagerer på når de omtaler mængden af engelske lån som "truende" eller "bekymrende", mere er denne amerikanisering end antallet af lån som sådan.

Ønsker man at måle engelskpåvirkningen af et sprog, skal man som tidligere nævnt bl.a. afgøre hvilke typer af lån man ønsker at undersøge. Man skal fx afgøre om pseudolån, der jo er dannet på hjemlig grund, skal betragtes som engelske låneord eller som danske dannelser, og 
man skal afgøre om paralleldannelser skal klassificeres som danske eller udenlandske dannelser. Man skal også bestemme om et ord som ninja, der er af japansk oprindelse, skal klassificeres som et lån fra japansk, eller om der er tale om et engelsk lån fordi vi sandsynligvis har lånt ordet via engelsk (Nørby Jensen 2019). Det samme gælder cancer, der af Gottlieb (2012: 174) gives som et eksempel på et engelsk ord som vi har indlånt pga. eufemisme, men som man også kunne vælge at kategorisere som et lån fra latin (jf. opslaget cancer i Den Danske Ordbog). Og endelig skal man afgøre om hybrider, der jo består af et dansk led og et udenlandsk led, skal betragtes som fremmed påvirkning (fx hvis ordet består af et oversat led og et indlånt led som i hårspray fra engelsk hairspray) eller som en dansk dannelse (som babysvomning, der er dannet herhjemme af det gamle lån baby + svomning).

Jørgen Nørby Jensen diskuterer i en artikel om neologismer i dansk hvordan man kan klassificere ord som hjemlige eller indlånte. Fx kan man fokusere på danskheden og de danske former og regne indirekte lån og paralleldannelser som danske dannelser; man kan også fokusere på ordenes oprindelse og gruppere de direkte lån, de indirekte lån og paralleldannelserne samlet, mens pseudolånene, der jo er dannet herhjemme, grupperes sammen med de danske dannelser (Nørby Jensen 2019: 214 ff.). Endelig kan man også fokusere på hvad der opleves som "fremmed", hvorved man udelukkende fokuserer på direkte lån og pseudolån. I den forbindelse skal man også afgøre om man vil undersøge alle ord der er blevet indlånt, uanset hvornår det er sket, eller om man vil sætte en "udløbsdato" (Rathje 2010: 160). Som oftest fravælges de allerældste lån ud fra det synspunkt at disse ord er så indarbejdede i modtagersprogets struktur at de ikke længere føles fremmede, men som Graedler (1998: 55) påpeger, er "fremmedhed" ikke noget man nødvendigvis kun forbinder med nye lån. Et nyere norsk lån som grunge ses således ofte i den helt tilpassede staveform gronsj og ser dermed mere norsk ud end $\mathrm{fx}$ et gammelt indlån som gentleman. Som oftest trækkes der en eller anden grænse for hvor gamle lån man opererer med, almindeligvis ved tiden omkring 2 . verdenskrigs slutning, hvor den engelske påvirkning jo for alvor tog fat.

I den offentlige debat er det som regel de lån der klart vidner om et engelsk ophav der fokuseres på, fordi det kræver et vist kendskab til 
engelsk at kunne klassificere de indirekte lån som danske oversættelser af engelske lån. Definerer man engelske lån som direkte lån, kommer man i dansk sammenhæng frem til at mellem $0,2 \%$ og $3 \%$ af ordene i løbende tekst er fra engelsk, afhængig af tekstart og genre (se Heidemann Andersen 2003: 28f. for en oversigt over danske forhold og Graedler 2007: 164ff. for en oversigt over nordiske forhold). Inddrager man også de indirekte lån, bliver procenten selvfølgelig højere, selvom den næppe bliver markant højere: Ældre undersøgelser viser således at låneord med engelsk ordstof er ca. to en halv gang så hyppige som oversættelseslån og betydningslån (Sørensen 1995: 58), men også her gælder det at frekvensen naturligvis afhænger af hvad man definerer som indirekte lån. Gottlieb (2019: 253) kategoriserer fx stavemåden focus (i stedet for den korrekte form fokus) og apostroffen i fx Hviid's Vinstue som eksempler på indirekte påvirkning fra engelsk, hvorved det samlede antal indirekte lån bliver højere end hvis man havde en anden mere snæver definition af indirekte lån.

Indirekte lån kan være svære at finde fordi de jo ligner hjemlige dannelser, og det kan også være vanskeligt med sikkerhed at klassificere dem som engelske lån. Begge dele kan være årsag til at man i den internationale anglicismeforskning ofte har undladt at inddrage indirekte lån i nævneværdig grad (Fiedler 2012: 247; Sunde 2019: 23ff.). Argumentet for at tage indirekte lån med i en undersøgelse af engelskpåvirkningen er at de kan betragtes som udtryk for en mere intensiveret påvirkning fordi de jo ikke anvendes pga. den åbenlyse prestige som forbindes med brugen af direkte lån, men påvirker sproget i det skjulte ved at etablerede danske ord, orddele og udtryk "nykombineres eller undergår indholds- eller udtryksændringer forårsaget af danske sprogbrugeres kontakt med engelsk" (Gottlieb 2019: 252). I Norge peger nye undersøgelser på at antallet af oversættelseslån af engelske fraser er i vækst (Sunde og Kristoffersen 2018), hvilket forklares med at nordmændene dels udsættes for en mere massiv påvirkning fra engelsk end hidtil, dels har et dybere kendskab til engelsk end tidligere. Også i andre europæiske sprog ser man en stigning $i$ antallet af oversatte fraser, fx i tysk (Fiedler 2012) og også i dansk (Gottlieb 2012).

\section{KULTURLÅN OG PRESTIGELÅN}


En anden inddeling af låneordene end den ovenfor skiteserede er baseret på lånenes semantiske indhold (Chrystal 1988: 193; Myers-Scotton 1993: 168 ff.; Matras 2009: 149ff.; Sunde 2019: 36), det vil sige i kulturlån (cultural loans) og prestigelàn ${ }^{2}$ (core loans). Kulturlån er lån der betegner nye genstande, fænomener e.l. der ikke tidligere fandtes i modtagersproget, og som der derfor ofte ikke findes nogen betegnelser for, $\mathrm{fx}$ computer, rock og quiz, mens prestigelånene supplerer eller erstatter lignende ord i modtagersproget (Haspelmath 2009: 48; Matras 2009: 150), fx sale for udsalg, team for hold og capsule wardrobe for basisgarderobe. Kulturlån accepteres ofte og kaldes "nødvendige" fordi de indlånes sammen med de ting og fænomener de betegner, men man kan diskutere om de er mere nødvendige end prestigelånene. I engelsk stammer ordet computer i betydningen 'A device or machine for performing or facilitating calculation' fra 1869 (OED 2020, opslag computer), og herfra er der så sket en betydningsudvidelse til den betydning af ordet vi kender i dag. Det ord som vi uden videre har accepteret i dansk, er altså oprindeligt en betydningsudvidelse i engelsk. Når Haspelmath (2009: 6) skriver at alle sprog potentielt har de sproglige resurser der skal til for at danne nye ord, er det et argument for at vi også herhjemme kunne danne et nyt ord for den teknologiske oprindelse som computeren er, ved hiælp af de sproglige byggeklodser vi allerede har. At vi kun sjældent gør det, har altså ikke rod i sproget, men i vores holdninger til hvad vi synes det er legitimt at optage af lån.

Mens kulturlånene i vid udstrækning accepteres, kritiseres prestigelånene ofte med den begrundelse at vi allerede har etablerede ord i sproget med samme betydning. Når Davidsen-Nielsen og Herslund (1999: 11) sondrer mellem "lån der beriger vores sprog, og lån der er overflødige", er det formentlig en sondring mellem kulturlån og prestigelån de henviser til, selvom man altså kan diskutere om computer er en større berigelse af sproget end team eller sideeffekt (hvor man ifølge de to forfattere lige så godt kunne bruge de hjemlige ord bold og bivirkning).

Kritikken af prestigelån som overflødige beror til dels på en noget ensidig opfattelse af at sprogets eneste funktion er at formidle ind-

2 En anden term er kjernelan, der fx bruges i norsk (se Sunde 2019: 36). Termen prestigelann (jf. Matras 2009: 150) anvendes her for at undgå forveksling med det som i denne artikel benævnes kerneord. 
holdet af det vi siger - og ikke også at være et udtryk for social og kulturel identitet (Preisler 1999: 40f). Prestigelån indlånes bl.a. fordi sprogbrugerne ønsker at identificere sig med långiversprogets kultur (Myers-Scotton 1993: 172) og med den prestige der forbindes med långiversprog (Winford 2010: 177). Ved brugen af prestigelån imiterer sprogbrugerne således "elements of the speech of a socially more powerful, dominant community in order to gain approval and social status. What this means in practice is that bilingual speakers associate certain elements within their repertoire with a particular set of contexts in which these elements are normally used" (Matras 2009: 150). Samtidig skaber de engelske lån også stilistisk variation i sproget, og prestigelån kommer derved ofte til at fungere som "stylistic gap-fillers", der komplementerer og fornyer ordforrådet (Graedler 1998: 216). Og selv der hvor et prestigelån ud fra en overfladisk betragtning kunne virke overflødigt fordi vi allerede har et eksisterende ord der betyder det samme, viser det sig ofte at ordene alligevel ikke betyder helt det samme. Det gælder eksempelvis sideeffekt, der betegnes som overflødigt (bl.a. af Davidsen-Nielsen og Herslund 1999) fordi vi allerede har bivirkning i sproget, men som ifølge Gottlieb (2004: 51) bruges på en lidt anden måde: Bivirkning bruges således primært i medicinske sammenhænge og har derudover ofte en negativ klang, mens sideeffekt har en mere neutral eller endda positiv klang. Dermed ser vi et eksempel på en udvikling som ikke er helt ualmindelig ved ordpar af denne type (jf. Weinreich 1953: 55), nemlig at det ene ord (her bivirkning) specialiseres. Den samme udvikling kan spores i finsk hvor traileri bruges om en trailer til at transportere $\mathrm{fx}$ en båd, mens det hjemlige ord peräkärry bruges om alle andre trailere (Battarbee 2002: 272), og det gælder et hjemligt ordpar som guide over for turistforer hvor guide er det der er mest udbredt $i$ almensproget, mens turisfforer er den officielle betegnelse i forbindelse med erhvervet (Jarvad 2014: 195). Vaskexgte synonymi er dermed (jf. Backus 1996: 121) et relativt sjældent fænomen.

\section{DATA:UGEBLADE OG EX ON THE BEACH}

Undersøgelsen her, der altså som nævnt skal fungere som et supplement til MiN- og MiD-projektets undersøgelser af engelskpåvirkningen af dansk avissprog, indeholder data fra forskellige ugeblade og ma- 
gasiner og fra en type talesprog. De to datasæt bliver her præsenteret, først ugebladene og dernæst talesproget.

\section{Ugeblade}

Der indgår i undersøgelsen 7 magasiner og ugeblade der er udvalgt på baggrund af deres indhold og målgruppe. Tidligere undersøgelser peger på at især unges sprog og det sprog der anvendes inden for forskning og teknologi, er præget af en tæt kontakt med engelsk (Poplack, Sankoff og Miller 1988: 48), og formålet med de forskellige blade og magasiner er derfor 1) at undersøge om der er flere engelske lån i blade til børn og unge end til voksne, og 2) at undersøge i hvilken udstrækning de forskellige blades indhold har betydning for antallet af engelske lån. De undersøgte blade er Vi unge, Fortnite, Illustreret Videnskab, Psykologi, Mad \& Bolig, Komputer for alle og Ude og Hjemme. Af disse blade henvender Vi unge, der omhandler tøj, makeup, kærester og venskaber, sig især til helt unge teenagepiger, mens Fortnite, der omhandler computerspillet af samme navn, henvender sig til børn og unge i 8-14-års-alderen. Illustreret Videnskab, Psykologi, Mad \&o Bolig, Komputer for alle og Ude og Hjemme henvender sig alle til voksne. Der er 2 af bladene (Mad \& Bolig og Ude og Hjemme) der indholdsmæssigt er koncentreret om hjemlige forhold, 1 blad (Komputer for alle) der omhandler it-teknologi, 1 blad der omhandler personlig udvikling og mentalt velvære (Psykologi), og 1 blad (Illustreret videnskab) der omhandler populærvidenskab.

\section{Ex on the Beach}

Det talesprog der undersøges til artiklen her, er det talesprog der anvendes $i$ de 10 første afsnit af sæson 1 af realityserien Ex on the Beach. I Ex on the Beach bliver en gruppe unge mennesker af begge køn (der ikke kender hinanden på forhånd) bragt sammen på en ferieø hvor de skal leve sammen $i$ en måned. Det forste danske afsnit af Ex on the Beach blev sendt i august 2018, og serien blev det mest sete program på Discovery Networks kanaler i samme periode (http://tvm.gallup. $\mathrm{dk} / \mathrm{tvm} / \mathrm{pm} / 2018 / \mathrm{pm} 1834$ _Consolidated.htm). Ex on the Beach er et realityprogram med unge deltagere og med unge som målgruppe, og formålet med at undersøge netop denne serie og det talesprog der anvendes $\mathrm{i}$ den, er forst og fremmest at kunne drage en sammenligning 
med Harriet Sharps afhandling fra 2001 om engelskpåvirkningen af svensk talesprog, hvor ét af hovedresultaterne var at mængden af engelske lån i svensk talesprog var relativt begrænset, dvs. omkring 2,5\% (Sharp 2001: 61). I Sharps undersøgelse indgår der bl.a. analyser af unge svenskeres talesprog i den såkaldte docusoap The Real WorldVisby, hvor man følger en gruppe unge mennesker i 3 måneder på et ferieresort i Visby. De unge der medvirker i Ex on the Beach, er mellem 21 og 26 år, mens de i The Real World er mellem 19 og 25 år, og der er $i$ begge undersøgelser tale om nogenlunde samme antal informanter, dvs. 6-7 stykker. Det sprog der tales i The Real World, karakteriseres som afslappet talesprog der har til formål at pleje og opretholde sociale relationer mellem ligesindede (Sharp 2001: 40 f.). Det samme kan sige siges om sproget i Ex on the Beach, men i begge tilfælde kan man diskutere i hvilken udstrækning der er tale om naturligt talesprog idet programmerne jo er skabt på baggrund af planlagte tv-produktioner hvor udvalgte deltagere placeres i et bestemt miljø og følges af et kamerahold døgnet rundt. Det er alt andet lige en situation der ikke vil føles naturlig for særligt mange, og dertil kommer at de mange timers tv-optagelser efterfølgende bliver klippet sammen til udsendelser af ca. 1 times varighed, formentlig således at de mere dramatiske optagelser (hvor deltagerne fx skændes) fylder mere end de optagelser hvor der er knap så meget dramatik. Det er dog altid forbundet med store vanskeligheder at indsamle naturligt talesprog fordi man er tvunget til at optage talesproget på en eller anden måde, og på den vis er Ex on the Beach-materialet ikke så meget anderledes end andre optagelser af talesprog. Derudover kan man sige at selvom man skal være forsigtig med at konkludere for meget om unges talesprog ud fra optagelserne alene, giver de dog stadig et indblik i og en forståelse af hvordan unge taler når de er sammen med andre unge i uformelle sammenhænge.

\section{METODEN}

Det indsamlede materiale er blevet excerperet med henblik på at finde engelske lån. Formålet med artiklen her er bl.a. at indsamle materiale der kan sammenlignes med MiN- og MiD-projektet, og engelske lån er derfor defineret som direkte lån, pseudolan og bybrider. Desuden er der kun medtaget lån som ifølge ordbøgerne er registreret i dansk første 
gang i tiden efter 1945. Dateringen af ordene er primært foretaget ved hjælp af Sprognævnets Nye ord i dansk fra 1955 til i dag (www.dsn.dk/ noid), Den Danske Ordbog (ordnet.dk/ddo), Ordbog over det danske Sprog (ordnet.dk/ods) og Sprognævnets ordsamling. Hensynet til sammenligneligheden med MiN- og MiD-projekterne betyder også at fraser (fx It's magic og Jeg vil ga efter peace in the valley), personavne, stednavne m.m. ikke er blevet excerperet ${ }^{3}$. Det har især haft betydning $i$ forhold til magasinet Fortnite, der jo som nævnt er baseret på det populære computerspil af samme navn, hvor betegnelser der stammer direkte fra spillet, fx Sparkle Supreme (Slow Dance) (der er en belønning man kan opnå for at klare en udfordring), Quinn the Outlander (navn på en person fra spillet) og Song of the Summer (navnet på en sang i spillet) ikke blevet excerperet. Man kan naturligvis diskutere om sådan noget som Sparkle Supreme (Slow Dance) skulle have været excerperet, men i betragtning af at der er tale om et begreb der relaterer sig direkte til det engelsksprogede spil, har jeg vurderet at der er tale om indlån på samme niveau som fx personnavne og stednavne, og har derfor valgt ikke at tage dem med. Hvis disse betegnelser indgår i en sammensætning (fx Stormwing-bandelse), er de dog taget med i lighed med MiN- og MiD-projektet. Endelig skal det nævnes at artiklen her udelukkende fokuserer på redaktionel tekst, dvs. at annoncer, reklamer osv. er talt fra. Dette skyldes først og fremmest at ikke alle de excerperede blade indeholder annoncer og reklamer. Det er kun mængden af engelske lån der undersøges, og lån fra andre sprog (fx latin og græsk) er dermed ikke taget med i undersøgelsen.

Det samlede antal ord i ugebladene er optalt manuelt. Der er taget flere forskellige stikprøver fra hver kilde således at der fx både indgår interviews, madopskrifter og produktomtaler i optællingerne. Annoncer, programoversigter, krydsord m.m. er ikke blevet excerperet og er dermed fratrukket det samlede antal ord. Ex on the Beach er blevet transskriberet af studentermedhjælpere i Dansk Sprognævn. De transskriberede tekster er lagt over i Word, der automatisk tæller antallet af ord.

3 I MiD-projektet excerperede man dog både fraser og udenlandske navne på danske personer og begivenheder, men de indgik ikke i sammenligningen med MiN-projektet. 


\section{LÅNEORDSFREKVENSEN}

Det samlede antal lån er udregnet i procenter i forhold til antallet af løbende ord i materialet. Resultatet fremgår af nedenstående tabel der viser antallet af løbende ord, antallet af engelske lån og låneordsfrekvensen i Ex on the Beach, i de excerperede ugeblade og i redaktionel avistekst (MiD-projektet).

TABEL 1. LÅNEORDSFREKVENS I EX ON THE BEACH, I UGEBLADE OG I REDAKTIONEL AVISTEKST

\begin{tabular}{llll}
\hline & Ex on the Beach & Ugeblade & $\begin{array}{l}\text { Avistekster } \\
\text { (MiD-projektet) }\end{array}$ \\
\hline Antal løbende ord & 81.851 & 166.799 & 117.537 \\
Antal låneord & 1.144 & 1.621 & 512 \\
Låneordsfrekvens & $1,4 \%$ & $1,0 \%$ & $0,4 \%$ \\
\hline
\end{tabular}

Det mest iøjnefaldende resultat er at antallet af engelske lån generelt er ret lavt. Som det ses, er der 1,4 \% engelske lån i Ex on the Beach mod $1 \%$ i ugebladene og $0,4 \%$ i redaktionelle avistekster ${ }^{4}$. Dermed er der altså mere end tre gange så mange engelske lån $\mathrm{i} E x$ on the Beach end der er i redaktionelt avissprog, men der er stadig lang vej til de $10 \%$ som indlægget i Berlingske Tidende, der blev nævnt i indledningen til artiklen her, refererer til. Umiddelbart bekræfter undersøgelsen altså tidligere undersøgelser der alle har vist at antallet af engelske lån frekvensmæssigt er relativt lavt.

Derudover skal det nævnes at der også er færre engelske lån $\mathrm{i}$ de excerperede ugeblade end i tidligere undersøgelser. I Pia Jarvads undersøgelse af antallet af engelske lån $i$ et ugeblad og et alment oplysende månedsblad (1995:109) var der således 3 \% direkte lån, altså ca. 3 gange så meget som i undersøgelsen her. Materialet er for spinkelt til yderligere analyser, men det er interessant at der i MiD-projektet blev konstateret et statistisk signifikant fald $i$ antallet af moderne importord $i$ aviserne fra 2016 i forhold til aviserne fra 2000 (Heidemann Andersen 2019a: 35 ff.). Dermed er der noget der kunne tyde på at vi i dag faktisk bruger færre engelske lån $\mathrm{i}$ dansk skriftsprog (det vil sige $\mathrm{i}$ avistekster

4 Forskellen mellem antallet af låneord i Ex on the Beach og ugebladene er statistisk signifikant $(\mathrm{p}<0,01)$. Det samme gælder forskellen mellem antal låneord i ugeblade og avistekster $(\mathrm{p}<0,01)$ og i Ex on the Beach og avistekster $(\mathrm{p}<0,01)$. Der er alle steder brugt Fischers eksakte test. Der er altså systematiske forskelle på de tre genrer ugeblade, avistekster og ungdoms-tv i det omfang stikprøverne er repræsentative for genrerne generelt. 
og ugeblade) end tidligere.

\section{Läneordsfrekvens i talesprog}

Som nævnt er det talesprog der anvendes i Ex on the Beach, sammenligneligt med talesproget i docusoapen The Real World. Det skal dog nævnes at Harriet Sharp i sin undersøgelse medregner alle lån fra engelsk, uanset hvornår de er blevet indlånt i svensk, og at hun også medregner navne. Imidlertid har Stig Johansson i en anmeldelse af Sharps afhandling fraregnet såvel proprier som ældre, veletablerede lån som job og film (med det formål at kunne sammenligne resultaterne med andre undersøgelser) og kommer derved frem til at der er 381 engelske lån i The Real World-korpusset, inklusive fraser (Johansson 2002: 96). Medregnes fraser blandt de engelske lån i Ex on the Beach, hvorved undersøgelserne bliver sammenlignelige, er der i alt 1283 engelske lån i Ex on the Beach. Derved kommer man frem til følgende tal for de to undersøgelser:

TABEL 2. LÅNEORDSFREKVENS I EX ON THE BEACH OG THE REAL WORLD

\begin{tabular}{lll}
\hline & Ex on the Beach & The Real World - Visby (Sharp 2001) \\
\hline Antal løbende ord & 81.851 & 76.000 \\
Antal låneord & 1283 & 381 \\
Låneordsfrekvens & $1,6 \%$ & $0,5 \%$ \\
\hline
\end{tabular}

Forskellen mellem låneordsfrekvensen $\mathrm{i}$ Ex on the Beach og The Real World er statistisk signifikant $(\mathrm{p}<0,01)$, og det viser at unge danske deltagere $i$ et realityprogram i dag bruger langt flere engelske lån end unge svenskere i et lignende realityprogram gjorde for knap 20 år siden. Der er dog stadig tale om et relativt lavt antal låneord, hvilket ifølge Johansson (2002: 97) kan hænge sammen med "the low lexical density of spontanous speech, i.e. the low proportion of lexical words in relation to function words" (Johansson 2002: 97). Den relativt lave låneordsfrekvens som Sharp når frem til i sin undersøgelse, er i modstrid med den opfattelse som mange har af at talesproget - og nok især unges talesprog - er meget engelskpåvirket. Denne forskel forklares med den fremtrædende plads som de engelske lån har i diskursen: "They stand out in the discourse and get noticed by members of the speech community" (Sharp 2001: 188), altså 
igen et argument om at de engelske lån er afstikkende i forhold til det resterende ordforråd. Desuden skal det bemærkes at antallet af engelske lån $\mathrm{i}$ Ex on the Beach ligger på nogenlunde samme niveau som i tidligere undersøgelser af mængden af engelske lån i unge danskeres talesprog, dvs. omkring $1 \%$ (Quist 2005; Rathje 2010).

Om forskellen mellem antallet af låneord i Ex on the Beach og $\mathrm{i}$ The Real World skyldes en generel stigning i brugen af engelske lån blandt unge i Skandinavien, eller om den blot skyldes en forskel blandt unge danskere $i$ forhold til unge svenskere, siger undersøgelsen ikke noget om. Det kunne derfor være interessant at sammenligne den danske udgave af Ex on the Beach med den svenske (og norske) udgave af samme program for derved at kunne lave en direkte sammenligning af brugen af engelske lån i samtidigt ungdomssprog i Skandinavien. En sådan undersøgelse er dog endnu ikke foretaget.

\section{Laineordsfrekvens i ugebladstekster}

Som vist $i$ tabel 1 ligger antallet af engelske lån i ugebladsteksterne på 1 $\%$. Imidlertid kan der være relativt stor spredning mellem de forskellige ugeblade, og det er derfor også blevet undersøgt hvor mange låneord der er i de enkelte blade. Dette er illustreret i tabel 3:

TABEL 3. LÅNEORD FORDELT PA KILDER

\begin{tabular}{lccl}
\hline Kilde & Antal løbende ord & Antal låneord & Låneordsfrekvens \\
\hline Fortnite & 5.420 & 163 & $3,0 \%$ \\
Illustreret videnskab & 21.515 & 158 & $0,7 \%$ \\
Mad \& Bolig & 22.374 & 85 & $0,4 \%$ \\
Psykologi & 26.000 & 352 & $1,4 \%$ \\
Vi unge & 39.935 & 376 & $0,9 \%$ \\
Komputer for alle & 5.715 & 310 & $5,4 \%$ \\
Ude og Hjemme & 45.840 & 177 & $0,4 \%$ \\
I alt & 166.799 & 1621 & $1 \%$ \\
\hline
\end{tabular}

Som det ses, er der en del variation i antallet af låneord i de forskellige 
blade. Antallet af låneord svinger fra 0,4\% i Ude og Hjemme og Mad \& Bolig til 5,4\% i Komputer for alle $5^{5}$. Det vil sige at de ugeblade der omhandler hjemlige forhold, har det laveste antal låneord, mens computermagasinet Komputer for alle ${ }^{6}$ indeholder flest låneord.

Det antages at den såkaldte elektroniske revolution, dvs. opfindelsen af computeren og hele it-teknologien, er en af de vigtigste grunde til den position som engelsk har i dag på globalt plan (Crystal 1997: 111 ff.), hvor computerrelaterede ord og begreber anvendes over store dele af verden. Også sammenlignet med andre naturvidenskabelige domæner hvor man kunne forvente en del engelske lån, fx kemi og fysik, dominerer it-teknologien i forhold til brugen af engelske lån (Hultgren 2012). Det er dermed ikke overraskende at Komputer for alle er det af de undersøgte blade der indeholder flest engelske lån.

Det magasin der indeholder næstflest lån, er Fortnite, der som tidligere nævnt er et blad henvendt til børn og unge der spiller det engelsksprogede onlinespil Fortnite. Computerspil, ikke mindst dem der er online, udgør i dag en vigtig del af mange børns og unges dagligdag, og via computerspillene kan man deltage $\mathrm{i}$ internationale fællesskaber på nettet hvor det fælles sprog er engelsk. Mange computerspil er engelsksprogede og bliver ikke oversat til dansk; det gælder også Fortnite, og det betyder fx at de genstande man kan anvende i spillet, har engelske navne, eksempelvis Stormwing, der er navnet på et krigsfly, og Quadcrasher, der er navnet på et køretøj, ligesom stednavne (fx Grid Island) også er engelske. Derudover er også betegnelserne på de udfordringer (fx Battle Pass: Road Trip) man skal prøve at vinde, samt de belønninger man kan opnå hvis man klarer udfordringerne (fx Tilted Technique (Hoodie)), på engelsk. Ingen af disse navne er talt med i undersøgelsen her, og det betyder at ugebladet Fortnite er mere engelskpræget end optællingerne her dokumenterer. I et tekstudsnit som det følgende er der således 3 engelske lån (mode, VIP og Fast Food-tårnet) der er blevet excerperet til undersøgelsen, og derudover

5 Det er bemærkelsesværdigt at computer her skrives med k. Staveformen med k "skulle signalere, at bladet talte et sprog, der var renset for engelske forkortelser, og presenterede informationer, som alle kunne bruge til noget" https://da.wikipedia.org/wiki/Komputer_for_alle). Dansk stavemåde signalerer altså tilsyneladende noget mere lavpraktisk end engelsk stavemåde.

6 Andelen af importord i Komputer for alle er signifikant højere end i det øvrige korpus $(\mathrm{p}<0,01)$. Andelen af importord er også signifikant højere i Fortnite end i det øvrige korpus $(\mathrm{p}<0,01$.). 
er der 2 engelske fraser og navne fra spillet (Sky station showdown LTM og Impulse Grenades), der ikke er blevet excerperet. Citatet lyder (med mine kursiveringer):

Sky station showdown LTM: I denne mode kæmper man mod andre hold om at indtage og kontrollere et område. Undervejs skal du forsvare din VIP, hvilket indebærer at klatre op af Fast Food-tairnet. Du skal også fjerne eventuelle fjender fra dit område ved hjælp af Impulse Grenades!".

Tekstudsnittet viser at der er relativt mange engelske lån i Fortnite, også flere end de $3 \%$ der er opført i tabellen. Andre undersøgelser af brugen af engelsk i computerspilsverdenen viser tilsvarende at der er en ret kraftig engelsk dominans (Kvamme Strømmen 2015; Sunde 2019), og dermed kan man gå ud fra at i hvert fald den (store) del af børn og unge der dagligt spiller computerspil, bliver udsat for en relativt kraftig engelskpåvirkning. Denne påvirkning ses ikke mindst i form af de mange engelsksprogede navne og fraser der indgår i spil som Fortnite - navne og fraser som ofte har en ret fremtrædende plads i teksten, og som det hyppigt kræver et vist engelskkendskab at kunne afkode. Dermed bliver de børn og unge der spiller eller læser Fortnite, altså eksponeret for en relativt kraftig engelskpåvirkning som en optælling af antallet af appellativer i løbende tekst ikke rigtig tager højde for, og det peger på at såvel navne som fraser bør indgå i fremtidige undersøgelser af engelskpåvirkningen af dansk skrift- og talesprog.

At der er relativt mange engelske lån i Fortnite, er dog ikke ensbetydende med at der generelt er mange engelske lån i de af de excerperede blade der henvender sig til børn og unge. I $V i$ unge er der således 0,9 $\%$ engelske lån i undersøgelsen her. Dette tal kan sammenlignes med en undersøgelse af Hye Christensen fra 2011 om amerikansk-engelsk påvirkning af dansk skriftsprog. I denne undersøgelse indgår der bl.a. 3 numre af $V i$ Unge, og det vises at antallet af engelske lån (defineret som direkte lån og hybrider) udgør mellem 1,07\% og 2,02\% af det samlede antal ord i et nummer af Vi unge fra hhv. 1960 og 1967. I 1974 ligger antallet af engelske lån på 1,93\%. Tallene fra Hye Christensens undersøgelse er oplistet i tabel 4 med årstallene 1960, 1967 og 1974, 
mens tallene fra 2018 stammer fra undersøgelsen her:

TABEL 4. ENGELSKE LÅN I VI UNGE I PERIODEN 1960 TIL 2018

\begin{tabular}{lllll}
\hline & $\begin{array}{l}\text { Vi unge } \\
1960\end{array}$ & $\begin{array}{l}\text { Vi unge } \\
1967\end{array}$ & $\begin{array}{l}\text { Vi unge } \\
1974\end{array}$ & $\begin{array}{l}\text { Vi unge } \\
2018\end{array}$ \\
\hline $\begin{array}{l}\text { Låneordsfrekvens } \\
\text { (direkte lån og hybrider }{ }^{\top} \text { ) }\end{array}$ & $1,07 \%$ & $2,02 \%$ & $1,93 \%$ & $0,94 \%$ \\
\hline
\end{tabular}

I Vi unge ligger antallet af engelske lån i 2018 på nogenlunde samme niveau som i 1960, og der er sket en halvering i forhold til 1967. Dermed bekræftes det fald vi også har set i antallet af engelske lån i avistekster og i ugeblade, og undersøgelsen tyder altså ikke umiddelbart på at engelske lån "strømmer ind i dansk", sådan som det ellers forlød $\mathrm{i}$ indlægget fra Flensborg Avis, i hvert fald ikke i det materiale der er undersøgt her. Det skal dog understreges at der er tale om et relativt spinkelt materiale, og at der derfor skal større undersøgelser til hvis denne tendens skal kunne bekræftes.

\section{KONKLUSION}

Hensigten med denne artikel har været at supplere allerede eksisterende undersøgelser af engelskpåvirkningen af dansk avissprog med undersøgelser af påvirkningen af dansk skriftsprog $i$ andre genrer og i uformelt talesprog. Undersøgelsens overordnede resultat er at der er signifikant flere engelske lån $\mathrm{i}$ de undersøgte ugebladstekster og $\mathrm{i}$ det uformelle talesprog der indgår i Ex on the Beach, end i redaktionelt avissprog, men at der stadigvæk samlet set er tale om et meget begrænset antal lån på under $2 \%$. I sammenligning med at den tyske indflydelse på det danske ordforråd antages at ligge på omkring 1617 \% (Mikkelsen 2008), er engelskpåvirkningen af dansk således ret beskeden når vi kigger på selve antallet af lån. Når mange danskere alligevel betragter engelskpåvirkningen af dansk som relativt kraftig og potentielt truende, skyldes det formentlig flere ting. For det forste springer de engelske lån ofte i øjnene, enten grafisk eller i form af deres nyhedsværdi, og for det andet tilpasses de engelske lån kun sjældent

7 De meget få lån der ikke er enten direkte lån eller hybrider i Vi unge fra 2018, er trukket fra, og undersøgelserne er dermed sammenlignelige. 
til dansk ortografi og fonologi og virker dermed afstikkende i forhold til resten af ordforrådet. Det gælder også kerneordene hvor de kerneord der er af engelsk oprindelse, ofte er utilpassede, mens de tyske og franske kerneord ofte er tilpasset dansk ortografi og dermed ikke virker fremmede mere. For det tredje findes der en del engelske lån i bestemte genrer der er beregnet til at fange vores opmærksomhed, $\mathrm{fx}$ reklamer og annoncer, og det betyder at de engelske lån ofte får en ret fremtrædende plads i sprogbrugerens bevidsthed. Endelig er det ikke uvæsentligt at der tilsyneladende er relativt mange engelske navne (og fraser) $i$ i hvert fald visse af de excerperede blade. De engelske navne er en del af den verden der omgiver os, og hvis man skal forstå hvorfor engelskpåvirkningen ofte føles mere massiv end de hidtidige frekvensoptællinger har dokumenteret, kunne man i fremtidige undersøgelser i højere grad fokusere på hvor mange engelske navne der findes i skriftligt og mundtligt dansk, fx på danske produkter og firmaer.

I indledningen til artiklen her blev der nævnt et citat fra Flensborg Avis og et fra Berlingske Tidende. Begge citater indeholdt en bekymring for det danske sprogs tilstand som ikke umiddelbart kunne genfindes $i$ hovedresultatet fra den ligeledes citerede forskningsrapport fra Dansk Sprognævn. Det er mit håb at artiklen her har vist at der måske ikke er langt mellem disse to forskellige holdninger som man umiddelbart kunne tro. Frekvensen af engelske lån er ganske rigtigt lav, tilsyneladende også i ugebladstekster og i uformelt talesprog, men det betyder ikke at man som dansk sprogbruger ikke stadigvæk godt kan være bekymret. De engelske lån har stor informationsmæssig tyngde, de fär meget opmærksomhed (fx i reklamer), de er påfaldende med deres engelske struktur, og de fylder meget i fx børne- og ungdomsspil som Fortnite. Denne bekymring har altså rod i noget der ikke umiddelbart har med frekvens at gøre, og hvis vi indser det, er det måske nemmere at få en diskussion med de bekymrede sprogbrugere af hvad det egentlig er der er bekymrende, end hvis man blot henviser til frekvensberetninger og signifikanstest. Forhåbentlig kan artiklen her anvendes i en sådan diskussion.

\section{TAK}


Tak til seniorforsker i Dansk Sprognævn Eva Skafte Jensen for gennemlæsninger, kritik og gode råd undervejs.

Margrethe Heidemann Andersen, seniorforsker

Dansk Sprognævn

heidemann@dsn.dk

\section{LITTERATUR}

Backus, A. 1996. Two in one. Bilingual speech of Turkish immigrants in The Netherlands. Tilburg: Tilburg University Press.

Bager Gandrup, M. 2019. Næste skridt kunne være at man helt slår over i engelsk. Berlingske.dk. 21. oktober 2019. https://apps.infomedia.dk/mediearkiv/link?articles $=$ e767acce (tilgået 1. maj 2020).

Battarbee, K. 2002. Finnish. M. Görlach (red.), English in Europe, 261-276. Oxford: Oxford University Press. DOI: 10.1093/acprof:oso/9780199273102.003.0014.

Capuz, J.G. 1997. Towards a typological classification of linguistic borrowing. (Illustrated with anglicisms in Romance languages). Revisita Alicantina de Estudios Ingleses 10. 81-94. DOI: 10.14198/raei.1997.10.08.

Chrystal, J.A. 1988. Engelskan i svensk dagspress. Stockholm: Skrifter utgivna av Svenska språknämnden 74 .

Crystal, D. 1997. English as a global language. Cambridge: Cambridge University Press.

Dansk Sprognævn. 2019. Engelske lån er ikkee en trussel. Pressemeddelelse. 18. november 2019. https://dsn.dk/nyt/nyheder/2019/pressemeddelelse-yes-det-er-coolt (tilgået 1. maj 2020).

Diderichsen, P. 2019. Moderne importord over tid i høj opløsning. M. Heidemann Andersen \& P. Jarvad (red.), Yes, det er coolt. Moderne Importord i Dansk, 63-163 (Sprognævnets konferenceserie, bind 6). Bogense. Dansk Sprognævn.

Davidsen-Nielsen, N. \& M. Herslund. 1999. Dansk han med sin tjener talte. N. Davidsen-Nielsen, E. Hansen \& P. Jarvad (red.), Engelsk eller ikeke engelsk. That is the question, 11-25 (Dansk Sprognævns skrifter 28). København: Gyldendal.

Den Danske Ordbog, http://ordnet.dk/ddo.

Edlund, L-E. \& B. Hene. 1992. Lainord i svenskan. Om spräkförändringar $i$ tid och rum. Forlägs AB Wiken.

Fiedler, S. 2012. Der Elefant im Raum... The influence of English on German phrase- 
ology. C. Furiassi, V. Pulcini \& F. Rodriguez Gonzáles (red.), The Anglicization of European Lexis, 239-259. Amsterdam: John Benjamin Publishing Company. DOI: $10.1075 /$ z.174.16fie.

Gellarstam, M. 1973. Etymologiske frekvenser i det centrala ordforrådet. Folkemålsstudier. Meddelanden frän Föreningen för nordisk. filologi 23. 70-79.

Gerritsen, M. \& F. van Meurs. 2013. Engelska i produktannonsering i icke-engelskspråkiga länder: Orsaker, använding och effekter. P.A. Lindblom, F-M. Kirsch \& A. Rubensson (red.), Såld på engelska? Om språkval i reklam och marknadsföring, 85-105. Stockholm: Språkforsvaret.

Gottlieb, H. 2004. Danish echoes of English. Nordic Journal of English Studies 3(2). 3966. DOI: $10.35360 /$ njes.161.

Gottlieb, H. 2012. Phraseology in flux: Danish Anglicisms beneath the surface. C. Furiassi, V. Pulcini \& F. Rodriguez Gonzáles (red.), The Anglicization of European Lexis, 169-198. Amsterdam: John Benjamin Publishing Company. DOI: 10.1075/z.174.13got.

Gottlieb, H. 2019. Danske anglicismer i GLAD-projektet. M. Heidemann Andersen \& P. Jarvad (red.), Yes, det er coolt. Moderne Importord i Dansk, 249-269 (Sprognævnets konferenceserie bind 6). Bogense: Dansk Sprognævn.

Graedler, A-L. 1998. Morphological, semantic and functional aspects of English lexical borrowings in Norwegian. Oslo: Scandinavian University Press, Universitetsforlaget.

Graedler, A-L. 2007. MIN-prosjektet jamført med tidligere studier. B. Selback \& H. Sandøy (red.), Fire dagar i nordiske aviser. Ei jamforing av påvernaden $i$ ordforrådet $i$ sju språksamfunn, 157-172 (Moderne Importord i Språka i Norden, bind 3). Oslo: Novus Forlag.

Haspelmath, M. 2008. Loanword typology: Steps toward a systematic cross-linguistic study of lexical borrowability. T. Stolz, D. Bakker \& R. Salas Palomo (red.), New theoretical, methodological and empirical findings with special focus on romancisation processes, 43-62. Berlin: Mouton de Gruyter.

Haspelmath, M. 2009. Lexical borrowing: Concepts and issues. M. Haspelmath \& U. Tadmor (red.), Loanwords in the world's languages. A comparative bandbook, 35-54. Berlin: De Gruyter/Mouton. DOI: 10.1515/9783110218442.35.

Heidemann Andersen, M. 2003. Engelsk $i$ dansk. Sprogholdninger $i$ Danmark. Helt vildt sjovt eller wannabeagtigt og ejendomsmaglerkakt? (Dansk Sprognæuns skrifter 33). København: Dansk Sprognævn.

Heidemann Andersen, M. 2018. Om afledningerne -agtig og -ish. Nyt fra Sprognaunet 
2018/3. https://dsn.dk/nyt/nyt-fra-sprognaevnet/numre/argang-2015-2019/ september-2018/september-2018 (tilgået 1. maj 2020).

Heidemann Andersen, M. 2019a. Moderne importord i danske avistekster. M. Heidemann Andersen \& P. Jarvad (red.), Yes, det er coolt. Moderne Importord i Dansk, 33-61 (Sprognævnets konferenceserie, bind 6). Bogense: Dansk Sprognævn.

Heidemann Andersen, M. 2019b. Yes, det er coolt. Moderne importord i danske aviser. Y. Goldshtein, I. Schoondeerbeek Hansen \& T. Thode Hougaard (red.), 45-57 (17. Mode om Udforskningen af Dansk Sprog). Aarhus: Aarhus Universitet.

Herslund, M. 1999. Dansk som "det andet sprog". N. Davidsen-Nielsen, E. Hansen \& P. Jarvad (red.), Engelske eller ikeke engelsk. That is the question, 19-24 (Dansk Sprognævns skrifter 28). København: Gyldendal.

Hultgren, A.K. 2012. Lexical borrowing from English into Danish in the sciences. An empirical investigation of 'domain loss'. International Journal of Applied Linguistics 23(2). 166-182. DOI: 10.1111/j.1473-4192.2012.00324.x.

Hye Christensen, H. 2011. AmeriDansk? En analyse af amerikansk-engelsk’ påvirkning af dansk i perioden 1945-1975. Amerikansk på Dansk: Arbejdspapir 6 (Sommer 2011). https://www.sdu.dk/-/media/files/om_sdu/institutter/ihks/projekter/ amerikansk+paa+dansk/artikler/ameridansk.pdf. (tilgået 1. maj 2020).

Jarvad, P. 1995. Nye ord - bvorfor og hvordan? København: Gyldendal.

Jarvad, P. 2014. Sporg om sprog - 40 år i Sprognaunets tjeneste (Dansk Sprognæuns skrifter 44). København: Dansk Sprognævn.

Jarvad, P. 2018. Engelsk. E. Hjorth et al. (red.), Ord for ord for ord, 429-452 (Dansk sproghistorie, bind 2). Det Danske Sprog- og Litteraturselskab. Aarhus: Aarhus Universitetsforlag.

Jarvad, P. 2019. Tilpasning af moderne importord til dansk. M. Heidemann Andersen \& P. Jarvad (red.), Yes, det er coolt. Moderne Importord i Dansk, 273-296 (Sprognævnets konferenceserie, bind 6). Bogense: Dansk Sprognævn.

Johansson, S. 2002. Review article: English influence on the Scandinavian languages. Nordic Journal of English Studies 1(1). 89-106. DOI: 10.35360/njes.92.

Kirchmeier-Andersen, S. 2009. En far står op for sine børn. Nye verber, nye konstruktioner. Nyt fra Sprognaunet 2009/4. 80-84. https://dsn.dk/nyt/nyt-fra-sprognaevnet/numre/argang-2005-2009/december-2009-pdf (tilgået 1. maj 2020).

Kvamme Strømmen, M. 2015. Han leashet ikk.je bot. No leash bot. Om bruken av engelsk 
språk hos eit knippe norske spelarar i ein norsk spelkontekst. Masteroppgave. Institutt for lingvistiske og nordiske studier. Universitetet i Oslo. https://www. duo.uio.no/bitstream/handle/10852/45084/StrommenMaster.pdf?sequence $=1$ \&isAllowed $=y$ (tilgået 20. maj 2020).

Ljung, M. 1985. Lam anka - ett màste? En undersökning av engelskan i svenskan, dess mottagande och spridning. EIS Report No. 8. Stockholm.

Lorentzen, H. 2018. Romanske sprog. E. Hjorth et al. (red.), Ord for ord for ord., 413428 (Dansk Sproghistorie, bind 2). Det Danske Sprog- og Litteraturselskab. Aarhus: Aarhus Universitetsforlag.

Maegaard, B. \& H. Ruus. 1978. DANwOrd. Hyppighedsundersøgelser i moderne dansk: Baggrund og materiale. Danske Studier 73. Universitets-Jubilæets danske samfund. 42-70.

Matras Y. 2009. Language Contact. Cambridge: Cambridge University Press. DOI: https://doi.org/10.1017/CBO9780511809873.

Meland S.I. 2019. Engelsk. lurer seg inn i norsk grammatike. https://gemini.no/2019/04/ engelsk-lurer-seg-inn-i-norsk-grammatikk (tilgået 1. maj 2020).

Mikkelsen, M. 2008. Tysk i dansk: Hovedleverandør til det danske sprog. Kristeligt Dagblad 21. november 2008. http://www.tysklaerer.dk/artikelarkiv/artikler/ 20081121krd3.pdf (tilgået 1. maj 2020).

Myers-Scotton, C. 1993. Duelling languages. Grammatical structure in codeswitching. Oxford: Oxford University Press.

Nilssen, S. 2015. 'Ei raudgron-ish dame som meg". Grammatisk og semantisk om det engelske (-ish) brukt i norsk. Kandidatspeciale. Universitet i Bergen.

Nørby Jensen, J. 2019. Antallet og arten af moderne importord i Nye ord i dansk 1955 til i dag. M. Heidemann Andersen \& P. Jarvad (red.), Yes, det er coolt. Moderne Importord i Dansk, 199-227 (Sprognævnets konferenceserie, bind 6). Bogense: Dansk Sprognævn.

Nørmark, J. 2020. Praktisk talt i wonderful Copenhagen. Bornholms Tidende 25. januar 2020. https://apps.infomedia.dk/mediearkiv/link?articles $=\mathrm{e} 78 \mathrm{~d} 89 \mathrm{c} 1$ (tilgået 1. maj 2020).

OED (Oxford English Dictionary). 2020. Oxford: Oxford University Press. https://www. oed.com/.

Ordbog over det danske Sprog, bind 1-28 (1919-1956) og supplementsbind 1-5 (1992- 
2005). http://ordnet.dk/ods.

Pedersen, I.L. 2000. Sprogkontakt, sprogpåvirkning - og sprogpolitik. Sprog i Norden 31(1). 34-44.

Pillar, I. 2001. Identity constructions in multilingual advertising. Language in Society (30). 153-186. DOI: 10.1017/S0047404501002019.

Poplack, S., D. Sankoff \& C. Miller. 1988. The social correlates and linguistic processes of lexical borrowing and assimilation. Linguistics 26. 47-104. DOI: 10.1515/ ling.1988.26.1.47.

Preisler, B. 1999. Engelsk ovenfra og nedenfra: Sprogforandring og kulturel identitet. N. Davidsen-Nielsen, E. Hansen \& P. Jarvad (red.), Engelsk eller ikke engelsk? That is the question, 39-64 (Dansk Sprognævns skrifter 28). København: Gyldendal.

Quist, P. 2005. Stilistiske praksisser i storbyens beterogene skole - en etnografisk og sociolingvistisk undersogelse af sproglig variation. Ph.d.-afhandling. Københavns Universitet.

Rathje, M. 2010. Generationssprog (Dansk Sprognævns skrifter 43). København: Dansk Sprognævn.

Ruus, H. 1991. Fælles danske ord. E. Hansen, I.L. Pedersen \& I. Poulsen (red.), Auditorium X. Dansk for, nu - og i fremtiden?, 158-180. Viborg: Amanda.

Ruus, H. 1995. Danske Kerneord. Centrale dele af den danske leksikalske norm, bind 1. København: Museum Tusculanums Forlag.

Sandøy, H. 2007. Avisspråket i Norden - ei jamføring. B. Selback \& H. Sandøy (red.), Fire dagar i nordiske aviser. Ei jamforing av påvernaden i ordforrådet i sju språksamfunn, 127-155 (Moderne Importord i Språka i Norden, bind 3). Oslo: Novus Forlag.

Sandøy, H. 2019. Prosjektet Moderne Importord i Språka i Norden. M. Heidemann Andersen \& P. Jarvad (red.), Yes, det er coolt. Moderne Importord i Dansk, 355-374 (Sprognævnets konferenceserie, bind 6). Bogense: Dansk Sprognævn.

Schack, J. 2019. Kerneimportord. M. Heidemann Andersen \& P. Jarvad (red.), Yes, det er coolt. Moderne Importord i Dansk, 239-248 (Sprognæwnets konferenceserie, bind 6). Bogense: Dansk Sprognæun.

Selback, B. \& H. Sandøy. 2007. Avisspråk og importord. B. Selback \& H. Sandøy (red.), Fire dagar i nordiske aviser. Ei jamforing av påvernaden i ordforrådet i sju språksamfunn, 9-24 (Moderne Importord i Språka i Norden, bind 3). Oslo: Novus Forlag.

Sharp, H. 2001. English in spoken Swedish. A corpus study of two discourse domains. Stockholm: Almqvist \& Wikell International.

Skafte Jensen, E. 2009. Adressere - om betydningsvarianter og mulige nydannelser. 
Nyt fra Sprognaunet 2009/3. 1-6. https://dsn.dk/nyt/nyt-fra-sprognaevnet/ numre/argang-2005-2009/september-2009-pdf (tilgået 1. maj 2020).

Skovgaard Boeck, S. 2018. Ældre nydansk. E. Hjorth et al. (red.), Ord for ord for ord, 303318 (Dansk Sproghistorie, bind 2). Det Danske Sprog- og Litteraturselskab og Aarhus Universitetsforlag

Sturlason, A.S. 2019. Det engelske sprog invaderer det danske. Berlingske. 20. januar 2019. https://apps.infomedia.dk/mediearkiv/link?articles=e70ca761 (tilgået 1. maj 2020).

Stålhammar, M. 2004. English influence on the Swedish vocabulary 1800-2000. Nordic Journal of English Studies 3(2). 85-100. DOI: https://doi.org/10.35360/njes.163.

Sunde, A.M. \& M. Kristoffersen. 2018. Effects of English L2 on Norwegian L1. Nordic Journal of Linguistics 41(3). 275-307. DOI: 10.1017/S0332586518000070.

Sunde, A.M. 2019. Skjult paivirkning. Tre studier av engelskpaivirkning $i$ norsk. Avhandling for graden philosophiae doctor. Norges teknisk-naturvitenskapelige universitet. https://www.researchgate.net/publication/335676976_Skjult_pavirkning_ Tre_studier_av_engelskpavirkning_i_norsk_Doktoravhandling (tilgået 20. maj 2020).

Sørensen, K. 1995. Engelsk i dansk. Er det et must? København: Munksgaard.

Thomason, S.G. \& T. Kaufman. 1988. Language contact, creolization, and genetic linguistics. Berkeley: University of California Press.

Weinreich, U. 1953. Languages in contact. Findings and problems. New York: Linguistic Circle of New York.

Winford. D. 2010. Contact and borrowing. Hickey, R. (red.), The handbook of language contact, 170-187. New Jersey: Wiley-Blackwell. DOI: 10.1002/9781444318159. ch8. 